\title{
Pharmacognostical Evaluation and Conservation of Threatened Species Curcuma caesia Roxb.
}

\author{
Research Article
}

\author{
Neelima Sharma ${ }^{*}$, Pankaj Prakash Verma ${ }^{2}$, Murthy $\mathrm{SN}^{3}$ \\ 1.Research officer (Ay.) 2. Research scholar 3. Assistant Director (S-4) \\ Regional Ayurveda Research Institute, Gwalior Road Jhansi
}

\begin{abstract}
Black turmeric Curuma caesia Roxb. is an important medicinal plant belonging to the family Zingiberaceae. Presently this plant is considered to be endangered by the central forest department of India.(1) Though the genus curcuma used for the treatment of various ailments but Curcuma caesia Roxb. is a very less known and almost untouched drug. The present work attempts to establish the necessary pharmacognostic and phytochemical standards for evaluating the medicinally and economically plant material of $c$. caesia. various parameters, such as morphology, microscopy, physiochemical constituents of the rhizome (medicinally and economically important plant part) was studied and the salient features are documented. To conserve the endangered species it is exercised to cultivate it in the central India i.e Jhansi by the rhizome cuttings.
\end{abstract}

Keywords: Curcuma caesia Roxb., Kali haldi, microscopy, Pharmacognostic, Conservation.

\section{Introduction:}

Curcuma is a large genus belonging to the family Zingiberaceae. It comprises about 70 species of rhizomatous herbs distributed mostly in Southeast Asia as wild and cultivated plants. Curcuma species have a great importance for its medicinal value and Curcuma caesia is being used by various tribal communities from long before. Kali haldi is a perennial herb with bluishblack rhizome native to North-East and Central India. Black Turmeric is also sparsely found in Papi Hills of East Godavari, West Godavari, and Khammam Districts of Andhra Pradesh.

This plant is native to North-East India, The rhizomes of black turmeric have a high economical importance owing to its high medicinal properties. Rhizome of the plant is claimed to be useful in treating several diseases like piles, leprosy, bronchitis, asthma, cancer, epilepsy, fever, wounds, impotency, fertility, toothache, and vomiting, etc.(2). In Madhya Pradesh the plant is regarded as very auspicious and is stated that a person keeping it will never have a scarcity of wealth. Presently this plant is considered to be threatened and endangered by forest department of India since natural habitat is destroying widely through several human activities such as over exploitation for traditional medicine purpose, industrialization and urbanization etc. (3).

\section{*Corresponding Author:}

\section{Neelima Sharma}

Research Officer (Ayurveda),

Regional Ayurveda Research Institute,

Gwalior Road Jhansi

E-mail: drneelimasharmayu@gmail.com

\section{Folk uses of the Curcuma Caesia Rhizome:}

The paste is applied on bruises, contusions and and rheumatic pains in Manipur (4). In Arunachal Pradesh, Adi tribes use decoction of fresh rhizome as anti-diarrhoetic (5). The khatmi tribe of Lohit district applied the paste of fresh rhizome in case of snake and scorpion bite (6). The rhizome are used a rubifient to rub the body after taking a Turkish bath. In Bengal, it is used in the fresh state-turmeric. The rhizomes of the herb are often used by the Baiga, Sahariya, Agariya, Gond, Korku and other tribal of the Madhya Pradesh state for the treatment of pneumonia, cough, and cold in children, and for fever and asthma in adults. In northeast India, the powder of rhizomes is used by tribal women as a face pack during their engagement and applied on the body for the sprains and bruises (7). Gondi people of Bastar apply rhizome paste on the hydrocele using betel leaves (8). Intake of small amount of rhizome paste is claimed to expel gases from the Stomach and cure menstrual disorders. The snake charmer community of the sub-urban areas of the capital city Bhubaneshwar Possess maximum knowledge in this regard. Therefore the plant Curcuma caesia Roxb. possesses many other economic values along with medicinal importance.

Therefore in the present study standardization of Curcuma caesia Roxb. has been done on pharmacognostic and phytochemical parameters.

\footnotetext{
Aims and objective

Recent literature review reveals that only a few work has been done regarding the pharmacognosy of the Curcuma caesia Roxb. (9). Present study is different as it contains Macroscpic study, Microscopic study, phytochemistry, and powder microscopy. Hence the present study with measurements of microscopic structures, powder microscopy will prove useful to researchers and professionals also. Therefore in the present study standardization of Curcuma caesia Roxb. has been done on pharmacognostic parameters.
} 


\section{Materials and Methods:}

\section{Collection of Plant material and authentication}

Plant was collected from the RARI Jhansi garden in flowering stage and authenticated at RARI Jhansi. The collected plant samples were washed under running fresh tap water to remove adherent soil and dirt. Three plant samples was collected, from the natural habitat. Rhizome for histological studies were preserved in $70 \%$ alcohol.

\section{Drying of plant material}

The Rhizome material of Curcuma caesia Roxb. was subjected to shade drying for about 4 weeks. The shade dried material was further crushed to powder and the powder was passed through the mesh 22 and stored in air tight container for further analysis.

\section{Macroscopic and microscopic analysis: Macroscopic study}

Macroscopic features were studied and photographs were taken with Nikon DSLR Camera (Fig:1,2).Macroscopic characters was studied with the help of flora and other literature. $(10,11,12,13)$.

\section{Morphology}

Collected rhizomes were observed carefully for its identical morphological characters.(Fig:3,4) Morphological characters like colour, shape, size were noted down. Characters of roots were studied as per taxonomy $(10,11,12,13)$ and measurement was taken by scale through naked eye.

\section{Microscopic analysis}

Microscopic examinations of plant studied were according to the standard method $(14,15)$. Transverse sections of rhizome were prepared and stained with saffranin and fast green as per procedure. Same procedure was followed for powder microscopy $(16,17)$. The microphotographs were taken by bright field microscope with digital camera.

\section{Extraction of powdered plant drug}

The plant material collected from their natural habitat was cleaned, shade dried and stored in an airtight glass container.100 gms. Of coarse powder was de-fatted with n-hexane and then successively extracted with different solvents viz. Petroleum ether, chloroform, Methanol(40-60) and ethanol in soxhlet extractor for $24 \mathrm{hrs}$ (for 8-9cycles). Then the extracts were filtered and concentrated using rotator flash evaporator. Freshly prepared extracts were subjected to phytochemical evaluation.

The method is used for separation of the natural products such as steroids, triterpinoids, glycosides, tannins, flavonoids, alkaloids, carbohydrate, proteins and saponins. (19-21).

\section{Result and discussion: \\ Organoleptic examination}

The inner part of the rhizomes is blackish blue in colour and emits a characteristic sweet camphoraceous smell, possesses aromatic pungent taste.
Macroscopic and microscopic analysis:

Macroscopic study:

The plant is normally erect with height ranging from $0.5-1.0 \mathrm{~m}$. It is divided into underground large ovoid tuberous rhizome and an erect aerial shoot along with leaves and reproductive part.

Leaves up to $50 \times 8 \mathrm{~cm}$., oblong-lanceolate, apex caudate-acuminate, base tapering. A deep ferruginous purple colour is present in the middle region of the lamina. Spikes $10-15 \mathrm{~cm}$. long, flowering bracts green with a ferruginous tinge; bracts of coma are deep pink. Flowers pale yellow pinkish at their outer border, shorter than their bracts. (Fig.1,2)

\section{Root:}

Plant propagates through rhizome, primary roots are absent, but brownish-yellow fibrous adventitious roots are present.( (Fig.3)

\section{Rhizome:}

The rhizome is tuberous about $2-6 \mathrm{~cm}$. in diameter, laterally flattened and covered with adventitious roots shows longitudinal circular wrinkles resemble as nodal and intermodal zones. Outer surface is dark brown in colour, inner surface is off white with bluish tinge shows blue coloured demarcation layer of endodermis separating the cortex from the central region. Small dots scattered throughout surface represent the vascular bundles. (Fig:3,4)

\section{Pharmacognostic Investigation}

The detailed and systematic pharmacognostical evaluation of Curcuma caesia Roxb.would give valuable information for future studies. The detailed morphology of Curcuma caesia Roxb. was carried out to support proper identification of the drug. Three samples of root are collected for microscopical studies. Histological features are found same in all the samples.

\section{Microscopy of Rhizome:}

The T.S. of the rhizome is circular with somewhat irregular outline and shows a layer of endodermis and wide central stellar region occupying $2 / 3^{\text {rd }}$ the area of the section, cortex being the narrow zone, both areas traversed by fibrovascular bundles and stellar region.(fig.6)

The detailed section shows an outermost single layer of very thick cells of epidermis covered with thick cuticle usually getting detached at places from the inner multilayered suberised cork tissue, cortex is wider, parenchymatous; consists of 3-5 layered thick walled parenchymatous cells; endodermis ill developed and a layer of pericycle is distinct and is devoid of starch grains, the vascular bundles of the cortex and stellar region are collateral and with the exception of those lying underneath the endodermis are associated with the groups of non lignified thin walled fibres; vessels are non lignified, often associated with a pigment cell; starch grains are simple and are loaded in cortical and stellar parenchymatous cells of section, isolated brown coloured oleo-resin canals, traversed throughout the parenchymatous tissue 
of the section. Pith large parenchymatous, a large number of cells are filled with starch grains or sphaeroraphides, a number of vascular traces traverse in the may be leaf traces.( (Fig.5-13).

\section{Result of Powder Microscopy: Colour-}

Powdered drug is ashy black to brownish black in colour with camphoraceous odour, taste is bitter; powder:-

Following characters were observed in the

Fragments of parenchymatous cells embedded with starch grains and oleoresin canals; plenty of simple oblong to elliptic starch grains, scattered throughout or embedded in parenchymatous cells. Fragments of xylem elements with pitted and spiral vessels and non septate fibers. ( (Fig.14)

\section{Preliminary Phytochemical Analysis:}

Preliminary phytochemical analysis of the Curcuma caesia Roxb. plant rhizome powder extract showed the presence of steroids, triterpinoids, glycosides, tannins, flavonoids, alkaloids, carbohydrate and proteins and saponins.

Table 1:Phytochemical constituent in plant Curcuma caesia Roxb. plant rhizome. (19-21)

\begin{tabular}{|l|l|l|l|}
\hline $\begin{array}{l}\text { Sl. } \\
\text { no. }\end{array}$ & $\begin{array}{l}\text { Class of } \\
\text { Compounds }\end{array}$ & & Test performed \\
\hline 1. & Steroids & + & $\begin{array}{l}\text { Burchard-Liebermann } \\
\text { test. }\end{array}$ \\
\hline 2. & Triterpinoids & + & $\begin{array}{l}\text { Burchard-Liebermann } \\
\text { test. }\end{array}$ \\
\hline 3. & Glycosides & + & Keller Killiani test. \\
\hline 4. & Saponins & - & Foam test. \\
\hline 5. & Tannins & + & Ferric chloride test. \\
\hline 6. & Flavanoides & + & Ammonia test. \\
\hline 7. & Alkaloids & + & Dragendorf's test \\
\hline 8. & Carbohydrates & + & Molish test \\
\hline 9. & Proteins & + & Millon test \\
\hline
\end{tabular}

\section{Conservation and Cultivation:}

Black turmeric rhizomes are procured from Itanagar Arunachal Pradesh and try to planted in RARI Jhansi garden. The land is prepared to a fine tilth and FYM is incorporated to the soil. The land is divided into flat beds of $5 \times 5 \mathrm{~m}^{2}$. Soil is sandy loam type, rhizomes are used as planting material and about $1 \mathrm{~kg}$ rhizome is required for $5 \times 5 \mathrm{~m}^{2}$. Rhizomes are planted $7 \mathrm{~cm}$. deep at a distance of $30 \times 45 \mathrm{~cm}$. Depending on the weather conditions the crop is irrigated at weekly intervals. Inflorescences are removed as and when they appear. The crop is ready for harvest after 8 months of planting. It can be micropropagated through tissue culture technique by rhizome buds explantants and using medium Murashige and Skoog(MS) medium containing 6-benzyl adenine(BA) alone or in combination with alpha Naphthalene acetic acid(NAA).(22)

\section{Conclusion:}

The plant with many curative principles and other economic values growing in all types of soil, climate etc. In this way its pharmacognostical standardisation and phytochemical analysis are very important to establish the uses of the plant more effectively.

In present investigation, various standardized parameters such as macroscopic, microscopic, pharmacognostic and phytochemical screening was carried out and which could be helpful in authentication of Curcuma caesia Roxb. The result of present study will also serve the reference material in prepration of monograph. Though the plant is categorized under the endangered species its cultivation and conservation is necessary therefore an attempt is made to cultivate the species in a different climatic zone. Its many uses are described in folk lore medicine. Therefore present study may help to pharmaceutical industries as well as researchers.

\section{References:}

1. https://en.wikipedia.org/wiki/curcuma caesia.

2. Muhammad Shahinozzaman, Molla Muhhammad ferdous, Muhammad Omar Faruq, Mustafa Abul Kalam Azad and Muhammad Nurul Amin, Micropropagation of black turmeric (Curcuma Caesia Roxb.) through in vitro culture of rhizome bud explants. Journal of central European Agriculture, 2013; 14(3), 963-968.

3. Arulmozhi DK, Sridhar N, Veeranjaneyulu A and Arora KS, Priliminary Mechanistic studies on the smooth muscle relaxant effect of hydraulic extract of curcuma Caesia. Journal of Herbal pharmacotherapy 2006; 6:(3/4).

4. Sarangathem $K$ and Haokip MJ, Bioactive components in Curcuma caesia Roxb. grown in Manipur, The Bioscan. 2015; 5(1): 113-115.

5. Kagyung R, Gajurel PR, Rethy $\mathrm{P}$ and sing B, Ethnomedicinal plant used for gastrointestinal diseases by Adi tribe of Dehang-debang biosphere reserve in Arunachal Pradesh, Journal of Traditional Knowledge. 2010; 9(3): 496-501.

6. Tag H, Das AK and Loyi H. Anti-inflammatory plant used by khatmi tribes of Lohit District in Arunachal Pradesh Natural product Radiation, 2007; (6)4: 340-343.

7. http//nopr.niscair.res.in/bitstream/123456789/1/ NPR\%206(4)\%20334-340.pdf

8. http://botanical.com/site/ column poudhia/66 hydrocele.html

9. Pritesh Paliwal, S.S. Pancholi, Rakesh K.Patel, Pharmacognostical parameters for evaluation of the rhizomes of Curcuma caesia. J. Adv. Pharm.Technol Res. 2011 Jan.-Mar; 2(1): 56-61.

10. Kirtikar KR and Basu BD, Indian medicinal plants., $2^{\text {nd }}$ Edition, Bishen Singh Mahendra pal Singh, Dehradun 1987, 2422.

11. Mudgal et al Flora M.P. 2001, Botanical Survey of India Calcutta, 80p

12. Anonymous, The Wealth of India. A dictionary of Indian raw materials and industrial products, 
New delhi, Publication and Information Directorate CSIR. 2001. 264p

13. Nadkarni KM. Indian material medica. Vol.1. Bombay: popular Prakashan; 1976. 414p.

14. Evans WC. Trease and Evans Pharrmacognosy, WB Saunders Ltd. London.2002.

15. Khandelwal KR. Practical Pharmacognosy. $18^{\text {th }}$ Edn. Nirali Prakashan, Pune.2007.

16. Khasim SM. Botanical Microtechnique: Principles $\&$ Practice. Capital Publishing Company, New Delhi.2002.

17. Kokate CK. Preliminary phytochemical screening. In $4^{\text {th }}$ Edn. Practical Pharmacognosy. Nirali Prakashan, Pune,India 2000.

18. Sahu R, Saxena J Evolution of phytochemical constituent in conventional and non-conventional species of curcuma. International Research Journal of Pharmacy 2012; 3(8); 203-204.
19. The Ayurvedic pharmacopoepia of India Government of India, Ministry of Health \& family welfare department of Indian system of Medicine and Homeopathy, Edn.1, New Delhi $2001 ; 3(1): 153$.

20. Kokate CK, Gokhle SB and Purohit AP. Textbook of Pharmacognosy. Nirali Prakashan Pune; 2008, 6.1-6.44.

21. Muhammad Shahinozzaman, Molla Muhhammad ferdous, Muhammad Omar Faruq, Mustafa Abul Kalam Azad and Muhammad Nurul Amin, Micropropagation of black turmeric (Curcuma Carsia Roxb.) through in vitro culture of rhizome bud explants. Journal of central European Agriculture, 2013, 14(3), p.963-968.

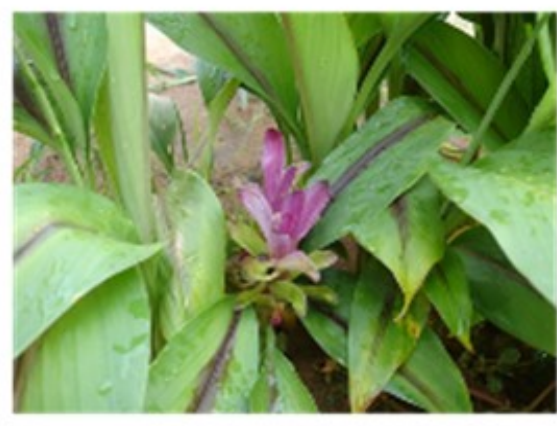

Fig:1 Curcuma caesia Roxb. In flowering

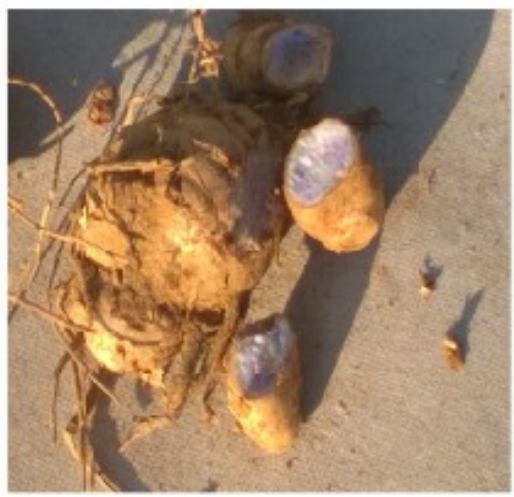

Fig: 3 Curcuma caesia Rhizcme external view

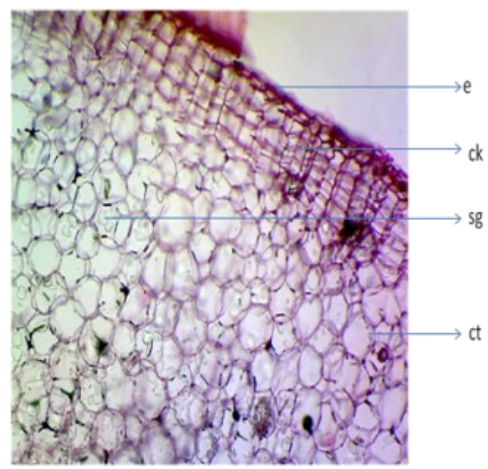

Fig.7:T.S. Curcumo coesio Rhizome at 10x showing epidermis and cortex

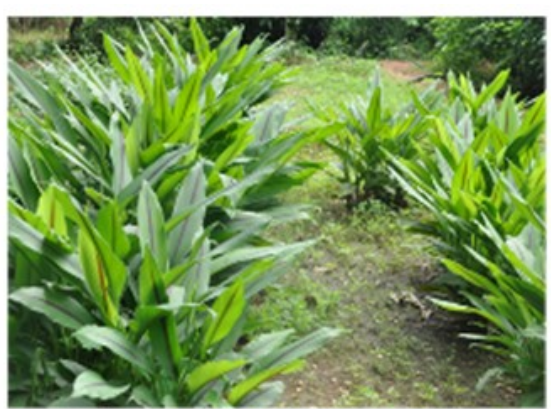

Fig: 2 Cultivation of Curcumo caesia Roxb.
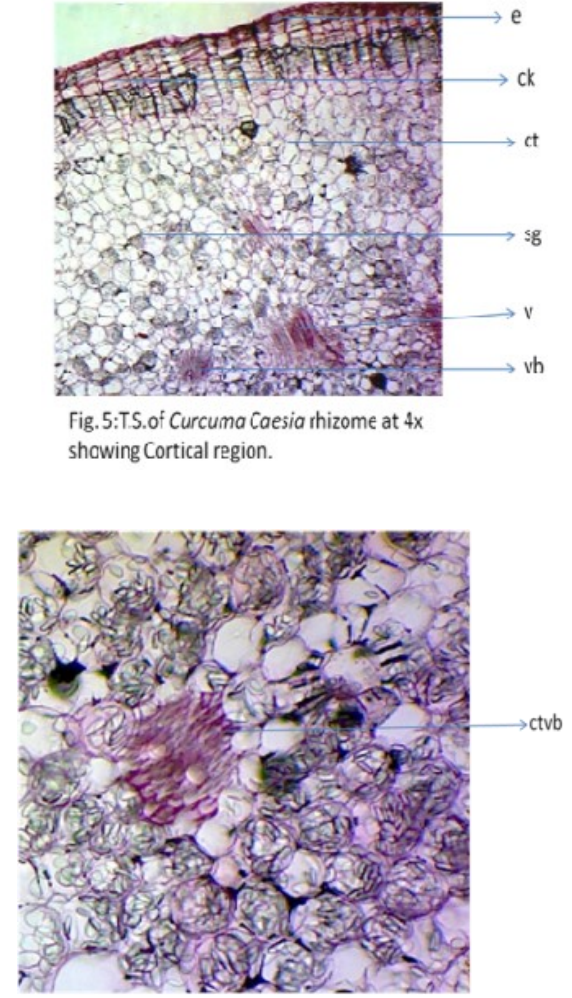

Fig. 8: T.S. Curcuma caesia rhizome at 10x showing cortex Region

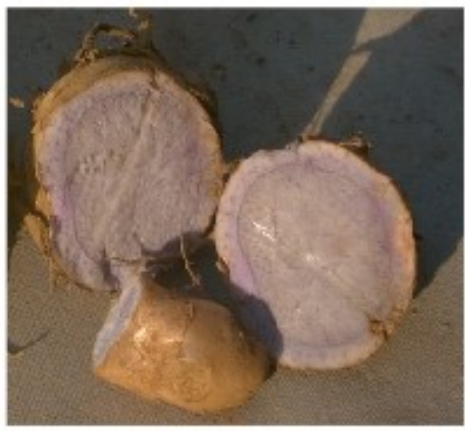

Fis : 4 Curcuma coesia Roxb. Internal view

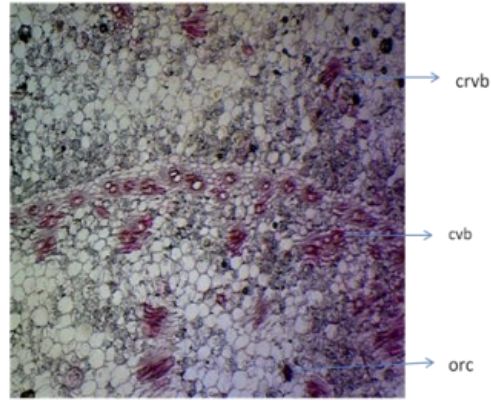

Fig.6: T.S. of Curcuma Caesia rhizome at $4 \mathrm{x}$ showing radial arrangement of vascular bundle

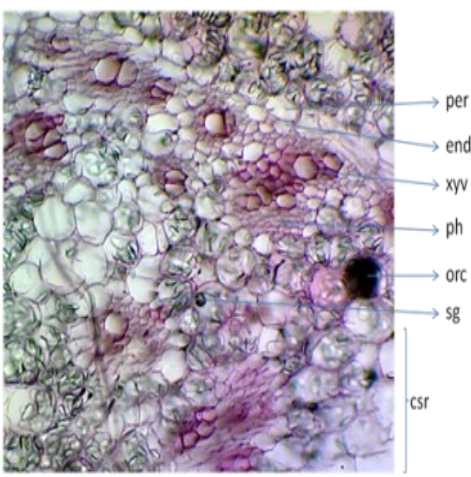

Fig.9:TS of Curcuma caesiarhizome at 10x Showing central stellar region 


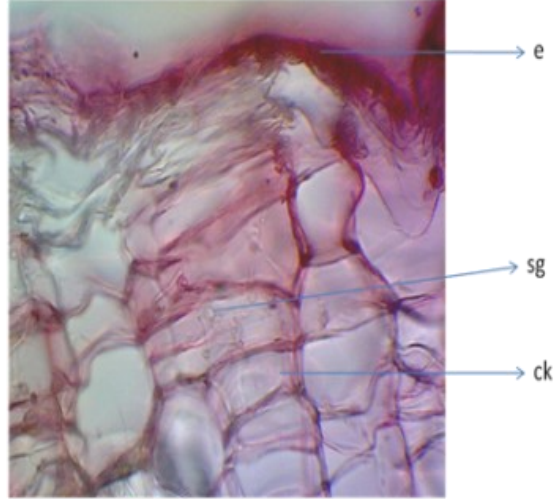

Fig.10:Fig.DT.S.of Curcuma Caesia rhizome at 40x showing epidermis and cork.

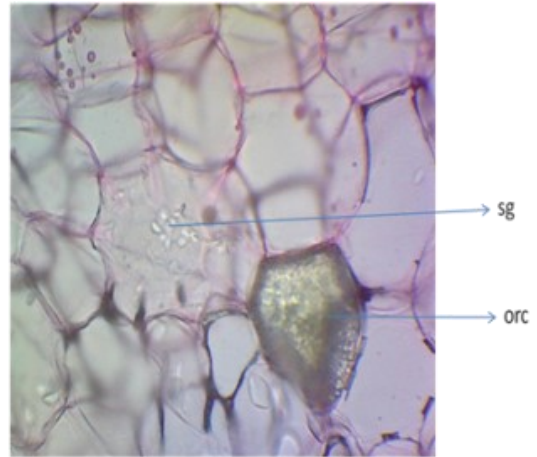

Fig.11:T.S. of Curcuma Coesia rhizome at 40x showing oleoresin cells and starch grains in cortex.

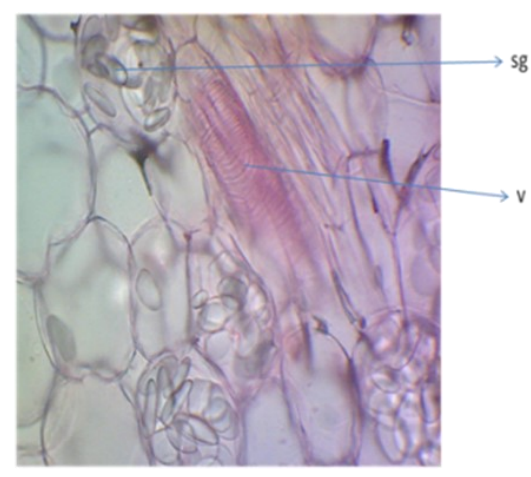

Fig. 11:T.S.of Curcuma Caesia rhizome at 40x showing xylem vessels.

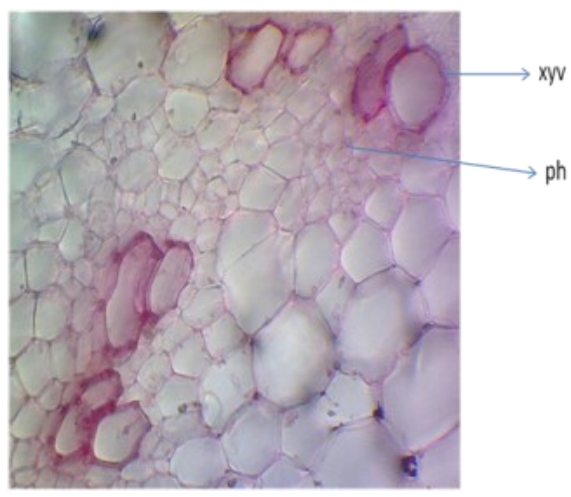

Fig.12: T.S.of Curcuma Caesia rhizome at 40x showing vascular bundle

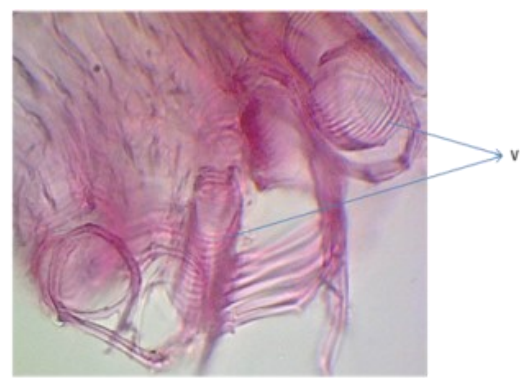

Fig.13: T.S.of Curcuma Caesia rhizome at 40 showing spiral vessels.

e, epidermis; ck, cork; sg, starch grains; ct, cortex ctvb, cortical vascular bundle; per, pericycle; end, endodermis; orc, oleoresin canals; xy, xylem vessels; ph, phloem; csr, central stellar region.

fig.14: Powder microscopy of Curcuma caesia Roxb. Showing A. Parenchymatous cells containing oleoresin cells and starch grains, B. anuler and spiral xylem vessels.C. Pitted xylem vessel,

D. starch Grains, E. Parenchymatous cells embedded with starch grains, f. cork cells, G. Cork cells containing oleoresin and starch grains $\mathrm{H}$. Non septate fibre. 